\title{
Compliance Status of Building Bylaws and Codes in High-rise Apartment Buildings of Nepal
}

\author{
Anjay Kumar Mishra*, Ganesh Karmacharya** \& P. S. Aithal*** \\ *Post Doctoral Research Scholar, Srinivas University, India and Associate Professor, Madan \\ Bhandari Memorial Academy Nepal, Urlabari-3, Morang, Nepal \\ OrcidID: 0000-0003-2803-4918; Email: anjaymishra2000@ gmail.com \\ ** Senior Division Engineer, Department of Urban Development and \\ Building Construction Division, Nepal Email; ganeshkarma038@ gmail.com \\ ***Professor, College of Management \& Commerce, Srinivas University, Mangalore, India \\ OrcidID: 0000-0002-4691-8736; E-mail: psaithal@gmail.com
}

Subject Area: Business Management.

Type of the Paper: Research Analysis.

Type of Review: Peer Reviewed as per $|\mathrm{C}| \mathrm{O}|\mathrm{P}| \mathrm{E} \mid$ guidance.

Indexed In: OpenAIRE.

DOI: http://doi.org/10.5281/zenodo.4774677

Google Scholar Citation: IJAEML

\section{How to Cite this Paper:}

Mishra, Anjay Kumar, Karmacharya, Ganesh, \& Aithal, P. S., (2021). Compliance Status of Building Bylaws and Codes in High-rise Apartment Buildings of Nepal. International Journal of Applied Engineering and Management Letters (IJAEML), 5(1), 66-79. DOI: http://doi.org/10.5281/zenodo.4774677.

International Journal of Applied Engineering and Management Letters (IJAEML) A Refereed International Journal of Srinivas University, India.

Crossref DOI : https://doi.org/10.47992/IJAEML.2581.7000.0093

(C) With Authors.

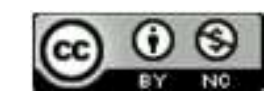

This work is licensed under a Creative Commons Attribution-Non-Commercial 4.0 International License subject to proper citation to the publication source of the work.

Disclaimer: The scholarly papers as reviewed and published by the Srinivas Publications (S.P.), India are the views and opinions of their respective authors and are not the views or opinions of the S.P. The S.P. disclaims of any harm or loss caused due to the published content to any party. 


\title{
Compliance Status of Building Bylaws and Codes in High-rise Apartment Buildings of Nepal
}

\author{
Anjay Kumar Mishra*, Ganesh Karmacharya** \& P. S. Aithal*** \\ *Post Doctoral Research Scholar, Srinivas University, India and Associate Professor, Madan \\ Bhandari Memorial Academy Nepal, Urlabari-3, Morang, Nepal \\ OrcidID: 0000-0003-2803-4918; Email: anjaymishra2000@ gmail.com \\ ** Senior Division Engineer, Department of Urban Development and \\ Building Construction Division, Nepal Email; ganeshkarma038@gmail.com \\ ***Professor, College of Management \& Commerce, Srinivas University, Mangalore, India \\ OrcidID: 0000-0002-4691-8736; E-mail: psaithal@gmail.com
}

\begin{abstract}
Purpose: The implementation and compliance of building bylaws and building codes in apartment buildings in Nepal are always questionable. Thus, the overall objective of the study was to assess the building bylaws and building code compliance in apartment buildings.

Design/Methodology/Approach: Data were collected by field observation of selected thirteen apartments and questionnaire survey after extensive literature review. It is analyzed based on the standard of codes and bylaws and effect during the earthquake and presented using charts, tables, and graphs.

Findings/Result: Though the provisions of bylaws i.e., greenery open space have not complied in four apartments and setback criteria have not complied in two apartments, all other provisions of bylaws have fully complied with in all thirteen apartments selected for the study. Likewise, most of the provisions of the Nepal National Building Code have fully complied in all thirteen apartments selected for the study. However, the RCC bands in masonry infill walls were not provided in all the thirteen selected apartments. The study revealed that the structural members in most of the apartments during the Gorkha earthquake 2015 were damaged minor to moderate only. But the nonstructural infill walls in most of the apartments were damaged moderately to severely. The main reason for severe to moderate damage on nonstructural infill walls of apartments was due to the RCC bands and vertical reinforcement not provided in the nonstructural walls. So, the RCC bands shall be provided in masonry infill walls and also the nonstructural masonry infill walls should be replaced in apartment buildings with lightweight, prefabricated materials to avoid damage in masonry infill walls. Similarly, the designer and developer himself should be made fully responsible and accountable for full compliance of building code and building Bylaws. Rewards and punishment systems should be introduced with the level of compliance with the provisions of codes and bylaws. Thus, the study revealed that the apartment building construction is a formal housing process regulated by the government of Nepal in the overall process of approval, supervision, and monitoring. The High-rise apartment buildings in Kathmandu valley are safe enough from earthquake, fire, and other natural disasters since the compliance with building codes and bylaws is satisfactory. Also, there is no option to go for High-rise Apartment buildings in the cities like Kathmandu where the land is very limited.
\end{abstract}

Originality/Value: It is empirical research to signify the compliance and contribution of building codes and bylaws

Paper Type: Ex-post facto project management research.

Keywords: building codes, bylaws, apartments, implementation, damages

1. INTRODUCTION :

The total value of disaster effects (damages and losses) caused by the Gorkha Earthquake 2015 in Nepal 
was US\$ 7.0 billion. The share of estimated total disaster effects among the main sectors of social and economic activity reveals that the most affected sector was the social sectors (58 percent of the total effects), which includes housing sector. The sector of housing and human settlements was the most affected one. The total effects (damages and losses) in social sector were valued at NPR 350,379 million, with the total damages amounting to NPR 303,631 million and the total losses estimated at NPR 46,748 million. The economic activity that has been hardest hit was that of real estate business, renting and business services, with annual growth projection revised downwards from 4.8 percent to 0.8 percent. There was a massive destruction of owner occupied dwellings and public assets worth over NPR 300 billion. Partly, because of their exposure to residential finance and real estate, the banking and financial institutions (BFIs) were likely to see modest deterioration in the quality of loan portfolios, impacting the solvency of institutions, micro and large, and the overall flow of credit (NPC, 2015) [1].

Thus, the issues about reliability and seismic safety of the high-rise apartment buildings in Kathmandu valley is to be assessed, which is directly related to the compliance of building Bylaws and building codes. The seismic safety of the high-rise buildings has been questioned by the public. The open spaces available around those high-rise buildings has also been questioned because of the situation experienced during the Gorkha Earthquake 2015. The issues raised by the neighbors about the safety of their own house and themselves from the high-rise apartment building is also to be addressed by the apartment buildings [2], [3] and [4].

Development of high-rise apartment building has been guided by the Ownership of joint housing act 1998, Building Act 1998, Nepal National building code (NBC), Building Bylaws of Kathmandu valley 2007 with respect to the seismic safety, fire safety of the apartment buildings and open spaces, setbacks, heights and access road widths required. Mostly the high-rise apartment buildings lie on the category "B", professionally engineered buildings according to the Building Act 1998. However according to NBC 000:1994 Requirements for State-Of-The-Art Design high-rise apartment buildings can be designed using the international codes such as IS Codes, New Zealand codes, British codes etc. satisfying the minimum requirement of NBC. Thus, implementation and compliance of building Bylaws and the building codes in high-rise apartment building construction for assurance of the seismic safety have been questioned after the Gorkha earthquake 2015 [2].

\section{OBJECTIVES :}

The purpose of the paper is to assess the status of compliance of building Bylaws and building codes in high-rise apartment buildings.

\section{LITERATURE REVIEW:}

\section{Implementation of Nepal National Building Code (NBC)}

The national building code was enforced for the governmental/semi-governmental buildings immediately after the building regulation 2003 was enacted. And NBC was enforced in 58 municipalities, 28 districts headquarter Village Development Committee (VDC) s and 76 others urbanizing VDCs after Government of Nepal published the gazette on February 13, 2006.

According to Building Act 1998, the main responsible authority for implementation of NBC in municipalities are the respective municipalities and in case of VDCs the main responsible government authority is respective Division office of Department of Urban Development and building construction (DUDBC). The responsible agency for overall monitoring and supervision of NBC implementation is DUDBC. Even several designs were presented for earthquake resistance building construction after earthquake as build back better concept and its implication on cost is increased but not significant in comparison to safety for general typology of buildings [3], [5] and [6]. There is a provision of Steering committee, Building Construction Management Upgrading (Consolidation) Committee, chaired by secretary of Ministry of urban development for regulating building construction work including building code formation, upgrading and monitoring and supervision of NBC implementation in the country.

Lalitpur sub-metropolitan city was the first to enforce NBC implementation in the building permit system in 2003. After this, the enforcement of NBC Implementation in other municipalities were started 
in very slow pace and up to the end of 2015 only 49 municipalities out of 217 municipalities (including newly declared municipalities) have been implementing NBC (DUDBC, 2016) [7]. The number of municipalities and respective year of enforcement till 2015 are shown in following chart.

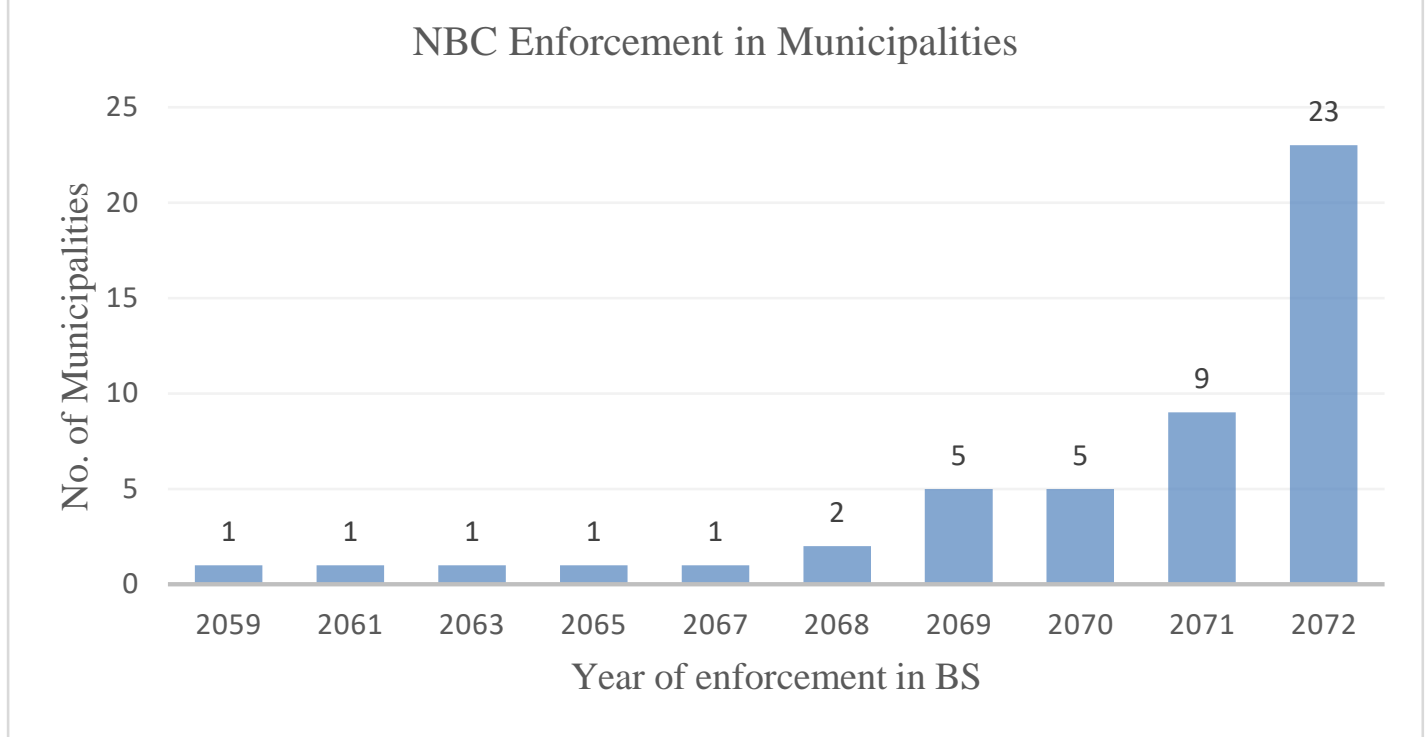

Fig. 1: Implementation Status of NBC in Municipalities

Source: (DUDBC, 2016) [7]

In case of High-rise apartment buildings, enforcement of National building code was started since the Ownership of Joint Housing Act, 1997 and Ownership of Joint Housing Rule, 2003 were enacted by GoN.

\section{Building Bylaws:}

As per Oxford learners Dictionary, Building Ordinance or Bylaws is the order, rule or law made by a Government or an authority. Building Bye-laws is promulgated by local authority Municipality. It is a part of the zoning in which the regulations are defined to regulate the use of the land. The Building Bylaws guides and controls the building activities within the lot to ensure safety, health, welfare to the people.

\section{RESEARCH METHODOLOGY :}

\section{Study Area}

Kathmandu valley is prime area for the study of building Bylaws and building code compliance in high rise apartment buildings. The high-rise apartment buildings, which were completed, in operation stage with inhabitants and damaged during the Gorkha Earthquake 2015, were the study area. The study was focused on the high-rise apartment buildings of Kathmandu Valley which were tagged with Green, Red and Yellow postages during the Rapid Visual Damage Assessment (RVDA) after Gorkha Earthquake 2015 and RVDA was conducted by DUDBC DoK to the apartments which were already completed and inhabited. Total thirteen apartments, Sunrise City Homes, Park View Horizon, TCH Tower 4, Silver City Apartment, Guna Colony and Oriental Dhumbarahi Apartment from Kathmandu district and Sunrise Apartment, The Residency Apartment, Sunrise Towers, City Escape Apartment, Westar Apartment-I, Westar OAK Apartment-II and Westar OAK Apartment-III from Lalitpur district are the selected apartments for study area. The Google map figure 1 shows the prime area of study and the table 1 shows the details of the selected apartments for study area.

\section{Study population, Sample selection and Sample size}

The total number of apartments in Kathmandu valley that have been completed and inhabited at the time of Gorkha Earthquake 2015 were 51 numbers. Department of Urban Development and Building Construction conducted Rapid visual Damage assessment (RVDA) in those 51 apartments. So, the target population of this study are the apartment buildings that have been completed and inhabited at the time of Gorkha Earthquake 2015 and included in Rapid Visual Damage Assessment after Gorkha Earthquake 2015. Out of 51 apartments two apartments got Red postage, eight apartments got Green 
postage and 41 apartments got Yellow postage according to the RVDA report (DUDBC, 2015) [9].

The Judgmental Sampling method was adopted taking into account of the degree of damage as per Rapid Visual Damage Assessment (RVDA) Report. Total thirteen apartments, one from Red stickered apartment, one from Green Stickered apartment and eleven numbers from Yellow stickered apartments, were selected for the study. Since the population of the Yellow stickered apartments are extremely higher than Red and Green stickered apartments, more number of apartments were selected from yellow and one/one number of apartment was selected from Red and Green stickered apartments each.

Similarly, the structural designers and Architects involved in apartment building design and construction were the respondents of the study. The ten architects involved in 14 apartments' design and ten structure engineers involved in 27 apartments' design were the respondents i.e., architects of 14 apartments and structural engineers of 27 apartments were the respondents of questionnaire survey in the study.

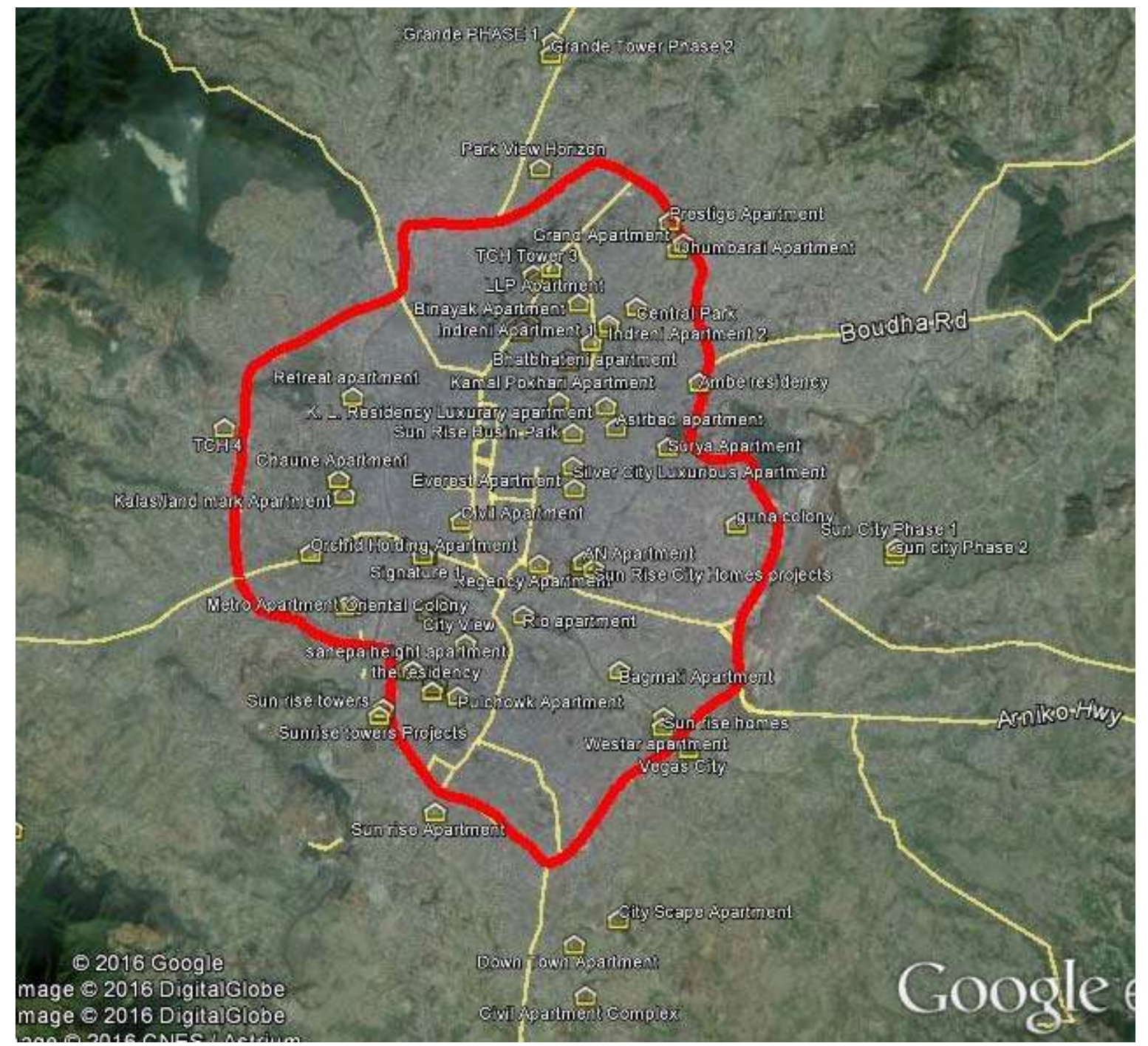

Fig. 2: Location map of high-rise apartment buildings

Source: (Google map, 2016)

Table 1: Details of selected apartments for study area

\begin{tabular}{|l|l|l|c|l|c|l|}
\hline $\begin{array}{l}\text { S. } \\
\text { N. }\end{array}$ & Apartment & \multicolumn{1}{|c|}{ Developer } & $\begin{array}{c}\text { Housing } \\
\text { Units }\end{array}$ & $\begin{array}{l}\text { Approval } \\
\text { Date }\end{array}$ & \multicolumn{1}{|c|}{$\begin{array}{c}\text { Project } \\
\text { status }\end{array}$} & $\begin{array}{l}\text { RVDA } \\
\text { Result }\end{array}$ \\
\hline 1 & $\begin{array}{l}\text { Park View Horizon, KMC- } \\
\text { 3, Dhapasi, Kathmandu }\end{array}$ & $\begin{array}{l}\text { Varun Developers Pvt. } \\
\text { Ltd, Dhapasi }\end{array}$ & 185 & $\begin{array}{l}\text { Jan. 6, 2008, } \\
\text { May 6, 2011 }\end{array}$ & $\begin{array}{l}\text { Completion } \\
\text { certificate }\end{array}$ & Red \\
\hline
\end{tabular}




\begin{tabular}{|c|c|c|c|c|c|c|}
\hline 2 & $\begin{array}{l}\text { TCH Tower 4, Sitapaila, } \\
\text { Kathmandu }\end{array}$ & $\begin{array}{l}\text { Comfort Housing pvt. } \\
\text { Ltd, Lazimpat }\end{array}$ & 67 & Oct. 24,2008 & $\begin{array}{l}\text { Completion } \\
\text { certificate }\end{array}$ & Yellow \\
\hline 3 & $\begin{array}{l}\text { Guna Colony, KMC 9, } \\
\text { Sinamangal, Kathmandu }\end{array}$ & $\begin{array}{l}\text { Stupa housing Pvt. Ltd, } \\
\text { Budhanagar }\end{array}$ & 160 & Jan. 6, 2008 & $\begin{array}{l}\text { Construction } \\
\text { completed }\end{array}$ & Yellow \\
\hline 4 & $\begin{array}{l}\text { Sunrise City Homes, } \\
\text { Bijulibazar Kathmandu }\end{array}$ & $\begin{array}{l}\text { Sunrise city homes } \\
\text { Developers Pvt. Ltd., } \\
\text { Basantapur. }\end{array}$ & 50 & April 6, 2008 & $\begin{array}{l}\text { Construction } \\
\text { completed }\end{array}$ & Yellow \\
\hline 5 & $\begin{array}{l}\text { Silver City Luxurious } \\
\text { Apartment, KMC- } \\
\text { 32, Kalikasthan, } \\
\text { Kathmandu }\end{array}$ & $\begin{array}{l}\text { Silver Valley Develope } \\
\text { rs pvt. Ltd., Kalikasthan }\end{array}$ & 54 & $\begin{array}{l}\text { September } \\
24,2009\end{array}$ & $\begin{array}{l}\text { Construction } \\
\text { completed }\end{array}$ & Yellow \\
\hline 6 & $\begin{array}{l}\text { Dhumbarahi Apartment, } \\
\text { Dhumbarahi, Kathmandu }\end{array}$ & $\begin{array}{l}\text { Oriental Builders and } \\
\text { developers p. Ltd., } \\
\text { Dhumbarahi }\end{array}$ & 164 & $\begin{array}{l}\text { April 13, } \\
2006 \text { \& June } \\
23, \quad 2009 \\
\text { (extension) }\end{array}$ & $\begin{array}{l}\text { Construction } \\
\text { completed }\end{array}$ & Green \\
\hline 7 & $\begin{array}{l}\text { City Escape } \\
\text { Apartment, Harisidhi, } \\
\text { Lalitpur }\end{array}$ & $\begin{array}{l}\text { CG Properties pvt. Ltd, } \\
\text { Sanepa }\end{array}$ & 197 & June 24, 2010 & $\begin{array}{l}\text { Construction } \\
\text { completed }\end{array}$ & Yellow \\
\hline 8 & $\begin{array}{l}\text { Sunrise Apartment, LSMC- } \\
\text { 13, Nakhu, Lalitpur }\end{array}$ & $\begin{array}{l}\text { Sunrise Developers pvt } \\
\text {. Ltd, Basantapur }\end{array}$ & 225 & $\begin{array}{l}\text { December } 29 \text {, } \\
2008\end{array}$ & $\begin{array}{l}\text { Completion } \\
\text { certificate }\end{array}$ & Yellow \\
\hline 9 & $\begin{array}{l}\text { Westar OAK Apartment- } \\
\text { II, LSMC -9, Balkumari, } \\
\text { Lalitpur }\end{array}$ & $\begin{array}{l}\text { Westar properties Pvt. } \\
\text { Ltd, Balkumari }\end{array}$ & 60 & $\begin{array}{l}\text { November } \\
11,2013\end{array}$ & $\begin{array}{l}\text { Construction } \\
\text { completed }\end{array}$ & Yellow \\
\hline 10 & $\begin{array}{l}\text { Westar PINE Apartment- } \\
\text { III, LSMC-9, Balkumari, } \\
\text { Lalitpur }\end{array}$ & $\begin{array}{l}\text { Westar properties Pvt. } \\
\text { Ltd, Balkumari }\end{array}$ & 72 & $\begin{array}{l}\text { November } \\
25,2013\end{array}$ & $\begin{array}{l}\text { Construction } \\
\text { completed }\end{array}$ & Yellow \\
\hline 11 & $\begin{array}{l}\text { Westar Apartment, LSMC- } \\
\text { 9, Balkumari, Lalitpur }\end{array}$ & $\begin{array}{l}\text { Westar properties Pvt. } \\
\text { Ltd, Balkumari }\end{array}$ & 80 & July 2, 2010 & $\begin{array}{l}\text { Construction } \\
\text { completed }\end{array}$ & Yellow \\
\hline 12 & $\begin{array}{l}\text { Sunrise Towers-I, LSMC-3, } \\
\text { Dhobighat, Lalitpur }\end{array}$ & $\begin{array}{l}\text { Sunrise Developers pvt } \\
\text {. Ltd, Basantapur }\end{array}$ & 160 & $\begin{array}{l}\text { August } 30, \\
2006\end{array}$ & $\begin{array}{l}\text { Construction } \\
\text { completed }\end{array}$ & Yellow \\
\hline 13 & $\begin{array}{l}\text { The Residency Apartment, } \\
\text { Sanepa Thadodhunga, } \\
\text { Lalitpur }\end{array}$ & $\begin{array}{ll}\text { Bajra } & \text { Sangrila } \\
\text { Residency } & \end{array}$ & 152 & $\begin{array}{l}\text { October 2, } \\
2011\end{array}$ & $\begin{array}{l}\text { Construction } \\
\text { completed }\end{array}$ & Yellow \\
\hline
\end{tabular}

Source: (DoK, 2017) [8]

\section{Primary Data Collection \\ Questionnaire Survey}

Two sets of questionnaires were set, one for structure designers and one for architects involved in apartment building design or construction. In the questionnaire for architects the first section was for Bylaws related questions, second section for building code related and third section about the scenario after the Gorkha Earthquake 2015. Similarly in the questionnaire for structural engineers the first section was for building code related questions and second section was for scenario of apartment after Gorkha Earthquake 2015. Ten questionnaires were distributed to structure engineers involved in apartment design or construction. On the other set of questionnaires also, ten questionnaires were distributed to architects involved in apartment building designs.

\section{Site Observation}

Site observation was a main tool of the data collection in the study. The two sets of the checklist, one for Bylaw's parameters and another for building code parameters with the Bylaws provisions, approved drawing provisions and site observation were used. The researcher visited the apartment building sites and the observation and required measurements were taken for compliance check as per approved design/drawings and provisions of building Bylaws and building code. 


\section{Secondary Data Collection}

\section{Literature Review}

The secondary sources such as approved drawings and designs of the apartments, reports of official publications, Semi-official publications and Private publications were also studied. The various unpublished data maintained by the departments and government offices, research papers and literatures were also reviewed.

\section{Data Analysis and Presentation}

This study used both qualitative and quantitative data. The quantitative data thus analyzed by using sample statistical techniques like average, mean, median, range. The results were presented in pie chart, bar diagram, tables. The qualitative data were analyzed thematically. The data are presented and interpreted in a logical manner.

\section{RESULTS AND DISCUSSION :}

\section{Compliance of Building Bylaws and Building Codes}

The third objective of the study was to find out the compliance level of building Bylaws and building codes in high rise apartment building construction. For this objective the site observation in thirteen apartments and the questionnaire survey with the structure engineers and architects involved in design and construction of the apartment building were done.

\section{Compliance of Building Bylaws in High-rise Apartments}

The results of the site observation for compliance of major provisions of building Bylaws and approved design, drawings as per checklist. All of the thirteen apartments considered for the study, comply the Bylaws provisions of Allowable Ground Coverage, Floor Area Ratio, Access road width, Front Setback, and Distance between two blocks. The Minimum Open space required for Greenery with water percolating to ground is not complied by four apartments i.e. Sunrise City homes, Sunrise Towers-I, Silver City Apartment and Guna Colony and complied by remaining nine apartments. Similarly Rear and Side setbacks required as per Bylaws were not complied by two apartments i.e. Sunrise Apartments and Sunrise Towers-I and complied by remaining eleven apartments of the study. Also, the summary of the above results is tabulated in table 2. According to the table 2, most of the apartments noncomplying the Bylaws provisions have got yellow postage during RVDA after Gorkha Earthquake 2015.

Table 2: Compliance of provisions of Building Bylaws in apartments considered

\begin{tabular}{|l|l|l|l|l|l|l|}
\hline \multirow{2}{*}{$\begin{array}{l}\text { S. } \\
\text { N. }\end{array}$} & \multirow{2}{*}{ Provisions of Building Bylaws } & \multicolumn{3}{l|}{ No. of Apartments } & \multicolumn{2}{l|}{$\begin{array}{l}\text { RVDA Postage of Non } \\
\text { complying apartment }\end{array}$} \\
\cline { 3 - 7 } & Comply & $\begin{array}{l}\text { Not } \\
\text { comply }\end{array}$ & Red & Yellow & Green \\
\hline 1 & Allowable Ground Coverage & 13 & 0 & - & - & - \\
\hline 2 & Floor Area Ratio (FAR) & 13 & 0 & - & - & - \\
\hline 3 & $\begin{array}{l}\text { Open space (unpaved and greenery } \\
\text { open to ground) }\end{array}$ & 9 & 4 & - & 4 & - \\
\hline 4 & Access Road width & 13 & 0 & - & - & - \\
\hline 5 & Front setback & 13 & 0 & - & - & - \\
\hline 6 & Side Setback & 11 & 2 & - & 2 & - \\
\hline 7 & Rear Setback & 11 & 2 & - & 2 & - \\
\hline 8 & Distance between two blocks & 13 & 0 & - & - & - \\
\hline & Total apartment considered in study & 13 no. & & & \\
\hline
\end{tabular}

The architects involved in apartment design and construction was asked "Are all the provisions of the building Bylaws fulfilled in construction as per approved architectural designs and master plans of the apartment?" The result is all provisions of Bylaws was fulfilled in $92.9 \%$ of apartments and partially fulfilled in only $7.1 \%$ of apartments. 
The result of both site observation and questionnaire survey shows that all of the provisions of Bylaws are not complied by all of the apartments.

\section{Compliance of Building Code in High-rise Apartments}

The results of the site observation for compliance of the provisions of building codes in apartment buildings as per national building code and approved design, drawings as per checklist. All of the thirteen apartments of the study, comply most of the provisions of building codes i.e., Width of staircase, tread width, Riser height and no. of risers per flight in staircase, maximum travel distance on floor to exits, Total width of exit door, Minimum size of ventilation shaft for water closet and bathroom, Typical column size and beam size as per design. Similarly, the soil Investigation report and NDT report were submitted by all of the apartments. Also, Fire safety requirements as per code i.e., total no. of stairs including fire escape stair, Fire hydrant system, Underground water tank capacity for fire requirement, internal hydrants and Yard hydrants were compiled by all of the thirteen apartments considered for the study.

However, the RCC bands required to be provided in unreinforced masonry walls i.e., sill band, Corner and Tee Stiches and vertical Rebars at corners and Tee junction of unreinforced wall were not provided by all of the thirteen apartments and only Lintel band was provided by all the apartments. So, this seems to be the main cause of extreme level of damages in nonstructural masonry walls of the apartments during Gorkha Earthquake 2015.The summary of the above results is tabulated in table 3:

Table 3: Compliance of provisions of Building code in Apartments considered

\begin{tabular}{|c|c|c|c|c|c|c|}
\hline \multirow{2}{*}{$\begin{array}{l}\text { S. } \\
\text { N. }\end{array}$} & \multirow{2}{*}{ Provisions of Building code } & \multicolumn{2}{|c|}{ No of Apartments } & \multicolumn{3}{|c|}{$\begin{array}{l}\text { RVDA Postage of Non } \\
\text { complying apartments }\end{array}$} \\
\hline & & Comply & $\begin{array}{l}\text { Not } \\
\text { Comply }\end{array}$ & Red & Yellow & Green \\
\hline 1 & \multicolumn{3}{|l|}{ Staircase } & & & \\
\hline 1.2 & Width of stair & 13 & 0 & - & - & - \\
\hline 1.3 & Tread width & 13 & 0 & - & - & - \\
\hline 1.4 & Riser height & 13 & 0 & - & - & - \\
\hline 1.5 & No. of risers per flight & 13 & 0 & - & - & - \\
\hline 2 & \multicolumn{3}{|l|}{ Exit } & & & \\
\hline 2.1 & $\begin{array}{l}\text { Max. travel distance to exit point in each } \\
\text { floor }\end{array}$ & 13 & 0 & - & - & - \\
\hline 2.2 & Total width of exit door & 13 & 0 & - & - & - \\
\hline 3 & $\begin{array}{l}\text { Min. size of ventilator for water closets } \\
\text { and bathroom }\end{array}$ & 13 & 0 & - & - & - \\
\hline 4 & Typical Column size & 13 & 0 & - & - & - \\
\hline 5 & Typical Beam size & 13 & 0 & - & - & - \\
\hline 7 & Soil Investigation report & 13 & 0 & - & - & - \\
\hline 9 & NDT test report & 13 & 0 & - & - & - \\
\hline 10 & \multicolumn{3}{|l|}{\begin{tabular}{|l|} 
Fire safety Requirements \\
\end{tabular}} & & & \\
\hline 10.1 & Emergency stairs & 13 & 0 & - & - & - \\
\hline 10.2 & Fire hydrant system & 13 & 0 & - & - & - \\
\hline 10.3 & $\begin{array}{l}\text { Underground water tank capacity for fire } \\
\text { requirement }\end{array}$ & 13 & 0 & - & - & - \\
\hline 10.4 & Internal fire hydrants & 13 & 0 & - & - & - \\
\hline 10.5 & Yard fire hydrants & 13 & 0 & - & - & - \\
\hline 12 & \multicolumn{3}{|l|}{ RCC Bands in unreinforced masonry } & & & \\
\hline 12.1 & Sill band & 0 & 13 & 1 & 11 & 1 \\
\hline
\end{tabular}




\begin{tabular}{|l|l|l|l|l|l|l|}
\hline 12.2 & Lintel band & 13 & 0 & - & - & - \\
\hline 12.3 & Corner Stiches if required & 0 & 13 & 1 & 11 & 1 \\
\hline 12.4 & Vertical rebar at corners and Tee junction & 0 & 13 & 1 & 11 & 1 \\
\hline
\end{tabular}

Besides the results of site observation, the results of the questionnaire survey with the structure engineers and architects involved in apartment design regarding the third objective of the study is discussed below:

The structure engineers were asked if the RCC bands and vertical rebar at corner and tee junction required for unreinforced masonry partition walls as per NBC were provided in the construction of apartment buildings they were involved and also, they were asked that did the seismic gap performed well in Gorkha earthquake 2015 and the results found is tabulated as in table 4.

Table 4: Status of RCC bands and vertical rebar and seismic gap

\begin{tabular}{|l|l|l|l|}
\hline S. & Question Asked & \multicolumn{2}{|l|}{ Structure Engineer } \\
\cline { 3 - 4 } N. & Yes \% & No \% \\
\hline 1 & $\begin{array}{l}\text { Were the RCC bands provided properly in unreinforced masonry walls } \\
\text { of apartment building as per NBC? }\end{array}$ & 66.7 & 33.3 \\
\hline 2. & $\begin{array}{l}\text { Were the vertical Rebars provided in Corners and Tee Junctions in } \\
\text { unreinforced walls of apartment buildings as per NBC? }\end{array}$ & 0 & 100 \\
\hline 3 & $\begin{array}{l}\text { Did the seismic gaps provided between two blocks of apartment building } \\
\text { performed well in Gorkha Earthquake 2015? }\end{array}$ & 85.2 & 14.8 \\
\hline
\end{tabular}

Table 4 shows that, $66.7 \%$ structure engineers expressed that the RCC bands were provided properly in unreinforced masonry walls of apartment building they were involved and $33.3 \%$ structure engineers expressed that RCC bands were not provided. Also 100\% structure engineers expressed their views that the vertical rebars were not provided in corners and Tee junctions of unreinforced walls of the apartment buildings they were involved. Again $85.2 \%$ structure engineers expressed their view that the seismic gap provided between two blocks performed well in Gorkha Earthquake and $14.8 \%$ structure engineers expressed their view that it did not performed well.

Also, the architects involved in apartment design and construction were asked "Are all the architectural design requirements as per NBC 206 complied in construction of apartment as per approved design?" And the result is $100 \%$ architects' view was all the architectural design requirements as per NBC 206 were compiled in construction of apartment as per approved design.

Since the Structure engineers were involved in design as well as the construction and geotechnical soil investigation shall be verified during construction while excavating the foundation and allowable bearing capacity of the soil used for design shall be confirmed during construction for safety of foundation. So, the structure engineers were asked "Was the Soil Investigation done to verify as per geotechnical investigation report during the period of construction after excavation?" The result was verification was done by visual inspection in $22.2 \%$, it was verified and confirmed with the soil type that was designed for in 37\%, Soil investigation and tests were carried out after excavation also in 29.6 $\%$ and no any verification was done in $11.1 \%$ apartment construction.

Similarly, the structure engineers were asked "what are those RCC bands provided in unreinforced walls of apartment building?" and the result was Sill band was provided in $59.3 \%$, Lintel band was provided in $59.3 \%$, corner band and other stiches were provided in $29.6 \%$ and all of the bands were provided in $29.6 \%$ apartments while no any bands were provided in $18.5 \%$ of apartment buildings.

Again, the structure engineers were asked "What do you think about the construction quality of the high-rise apartment buildings?" and the result was $29.6 \%$ of apartments' have the good quality construction and $70.4 \%$ apartments construction quality was satisfactory while none of the apartments construction quality was in partially satisfactory and not satisfactory.

Similarly, the structure engineers were asked about the problems in effective implementation of code and Bylaws giving five options "What are the problems you feel for effective implementation of building code and bye-laws in apartment?" and for the result the given identical views were grouped 
and shown in figure 3.

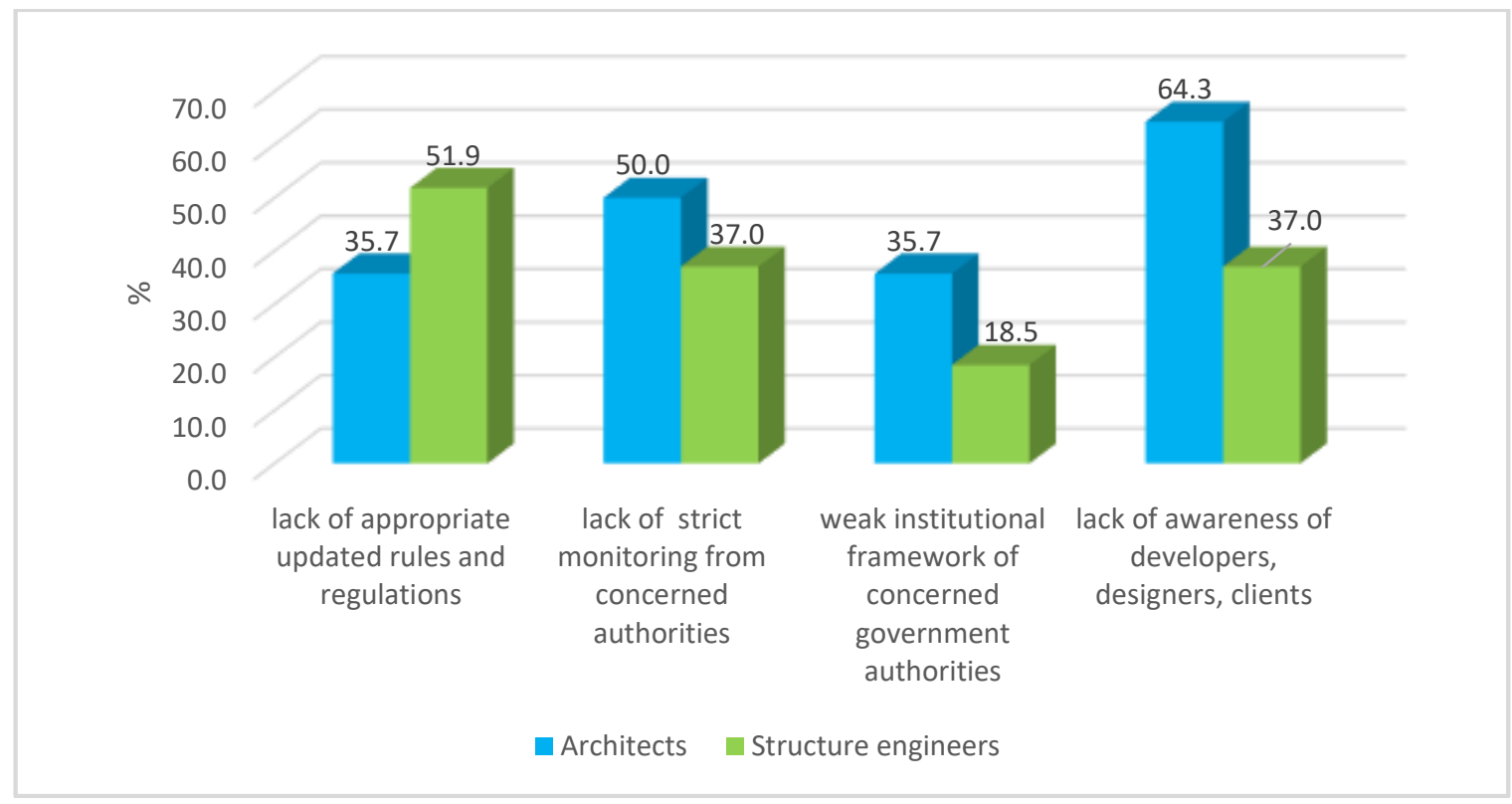

Fig. 3: Issues in effective implementation of Bylaws and code

Figure 3 shows that the issues in effective implementation of the building code and building Bylaws are "lack of appropriate updated rules and regulations" which was expressed by $35.7 \%$ architects and $51.9 \%$ structure engineers, "lack of strict monitoring from concerned authorities" was expressed by $50 \%$ architects and 37\% structure engineers, "weak institutional framework of concerned government authorities" was expressed by $35.7 \%$ architects and $18.5 \%$ structure engineers and "lack of awareness of developers, designers, clients" was expressed by $64.3 \%$ architects and $37 \%$ structure engineers.

Likewise, both the architects and the structure engineers were asked "What kind of policy recommendation do you suggest for effective implementation of building codes and building Bylaws in apartment building construction?" The expressed identical suggestions were grouped and the result is shown in figure 4.

Figure 4 shows that for the effective implementation of the building Bylaws and code "Strict monitoring and supervision from DoK" was recommended by $71.4 \%$ architects and $55.56 \%$ structure engineers, "update of code and Bylaws" recommended by $51.7 \%$ architects and $37.04 \%$ of structure engineers, "clear role and responsibility mentioned for all concerned authorities" was recommended by $42.9 \%$ architects and $7.41 \%$ structure engineers, "third party verification, supervision and monitoring mechanism" was recommended by $28.6 \%$ architects and $37.04 \%$ structure engineers and "Fine and punishment system for violation of rules" was recommended by $42.9 \%$ architects and $14.81 \%$ structure engineers.

Similarly, to find out the scenario of the high-rise apartment buildings after Gorkha Earthquake 2015 in April 25, 2015 the questionnaire both structure engineers and architects were asked "How can the risks from high-rise apartments and issues concerning to the neighbors during the earthquake be minimized?" and the result of those questions are grouped with identical ones and shown in table 5.

Table 5 shows that according to views of architects and structure engineers the risks from high-rise apartments and the issues concerning to the neighbors during the earthquake can be minimized by sufficient setback, less FAR and less ground coverage which was expressed by $78.6 \%$ architects and 96.3\% structure engineers, by Proper Zoning for apartment construction which was the view of $64.3 \%$ architects and $81.5 \%$ structure engineers. Also $7.1 \%$ architects and $11.1 \%$ structure engineers expressed that the risk can be minimized by doing seismic vulnerability assessment and assured seismic safety, $22.2 \%$ structure engineers expressed that by the insurance of neighbors and $28.6 \%$ architects and $33.3 \%$ structure engineers expressed their views that the risk can be minimized by assurance of quality of apartment construction. 


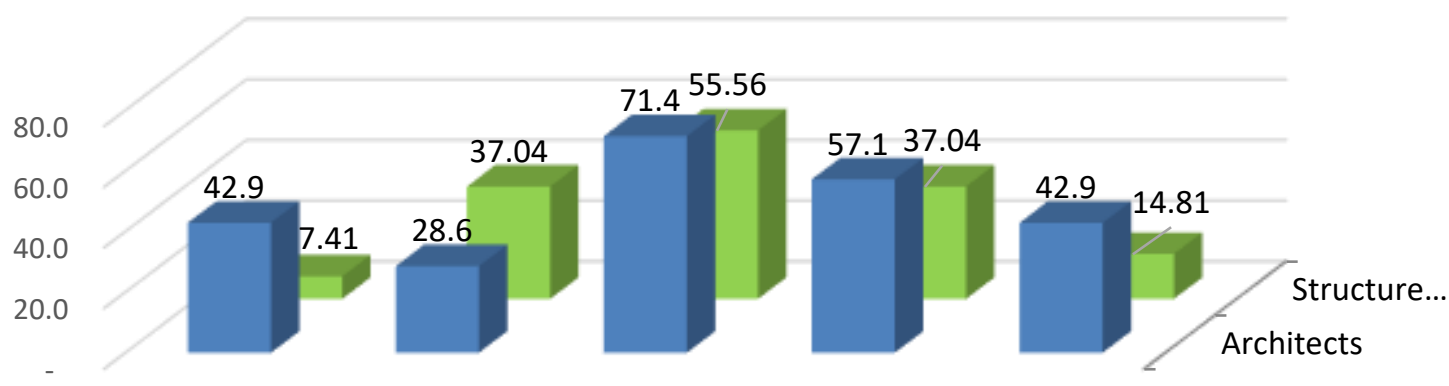

$$
\begin{aligned}
& \text { Clear Role and Third party Strict Update of Fine and } \\
& \text { resposibility Verification monitoring code and punishment } \\
& \text { mentioned and and byelaws system for } \\
& \text { supervision \& supervision voillation of } \\
& \text { monitoring from DoK rule }
\end{aligned}
$$

mechanism

Architects $\square$ Structure engineers

Fig. 4: Designers' perception about implementation of Bylaws and code

Table 5: Recommendations to minimize issues concerning the risks to neighbors

\begin{tabular}{|l|l|l|l|l|}
\hline \multirow{2}{*}{$\begin{array}{l}\text { S. } \\
\text { N. }\end{array}$} & Question Asked & $\begin{array}{l}\text { Views for minimizing Risks and } \\
\text { solving issues }\end{array}$ & $\begin{array}{l}\text { Architect } \\
\mathrm{s}\end{array}$ & $\begin{array}{l}\text { Structure } \\
\text { Engineer } \\
\mathrm{s}\end{array}$ \\
\hline 1 & $\begin{array}{l}\text { How can the risks from high-rise } \\
\text { apartments and issues concerning to } \\
\text { the neighbors during the earthquake } \\
\text { be minimized? }\end{array}$ & $\begin{array}{l}\text { Sufficient Setback, Less FAR and } \\
\text { less Ground coverage }\end{array}$ & $78.6 \%$ & $96.3 \%$ \\
& $\begin{array}{l}\text { Proper Zoning for apartment } \\
\text { construction }\end{array}$ & $64.3 \%$ & $81.5 \%$ \\
\cline { 3 - 5 } & $\begin{array}{l}\text { Seismic vulnerability assessment } \\
\text { and assured seismic safety }\end{array}$ & $7.1 \%$ & $11.1 \%$ \\
\cline { 3 - 5 } & Insurance of neighbors & $0 \%$ & $22.2 \%$ \\
\cline { 3 - 5 } & Assurance of quality & $28.6 \%$ & $33.3 \%$ \\
\hline
\end{tabular}

\begin{tabular}{|c|c|c|c|c|c|c|c|c|c|}
\hline \multirow[b]{2}{*}{$\begin{array}{l}\text { S. } \\
\text { No. }\end{array}$} & \multirow[b]{2}{*}{ Question Asked } & \multicolumn{4}{|c|}{ Architects } & \multicolumn{4}{|c|}{ Structure Engineers } \\
\hline & & $\begin{array}{l}0 \\
\stackrel{0}{0} \\
\stackrel{0}{n}\end{array}$ & 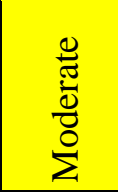 & $\stackrel{\dot{0}}{\Xi}$ & 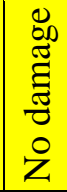 & $\begin{array}{l}0 \\
\dot{0} \\
\vec{J} \\
\tilde{D}\end{array}$ & 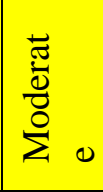 & $\stackrel{\dot{\sigma}}{\Xi}$ & 之 \\
\hline 1 & $\begin{array}{l}\text { What type of Structural damages } \\
\text { did you observed in the } \\
\text { apartment building you were } \\
\text { involved after earthquake? }\end{array}$ & 0 & $14.3 \%$ & $\begin{array}{l}85.7 \\
\%\end{array}$ & 0 & 0 & $\begin{array}{l}29.6 \\
\%\end{array}$ & $\begin{array}{l}70.4 \\
\%\end{array}$ & $0 \%$ \\
\hline
\end{tabular}

To find out the scenario of structural and non-structural damage condition in the high-rise apartment buildings after Gorkha Earthquake 2015, both structure engineers and architects were asked about the scenario and the result is shown in table 6.

Table 6: Scenario of damages in Apartments from Gorkha Earthquake 2015 


\begin{tabular}{|l|l|l|l|l|l|l|l|l|l|}
\hline 2 & $\begin{array}{l}\text { What type of Non-structural } \\
\text { damages did you observed in the } \\
\text { apartment building you were } \\
\text { involved after earthquake? }\end{array}$ & 14.3 & $42.9 \%$ & $\begin{array}{l}42.9 \\
\%\end{array}$ & 0 & $\begin{array}{l}44.4 \\
\%\end{array}$ & $\begin{array}{l}29.6 \\
\%\end{array}$ & $\begin{array}{l}25.9 \\
\%\end{array}$ & 0 \\
\hline
\end{tabular}

According to table 6,14.3\% architects and $29.6 \%$ of structure engineers expressed that the structural damages were Moderate type of damage in the apartments they were involved and $85.7 \%$ architects and $70.4 \%$ of structure engineers expressed that the structural damages were Minor damage in the apartments they were involved. This means there were minor type of damage in most of the apartments building. Also $14.3 \%$ architects and $44.4 \%$ structure engineers expressed that the nonstructural members were severely damaged, $42.9 \%$ architects and $29.6 \%$ structure engineers expressed that the nonstructural members were moderately damaged and $42.9 \%$ architects and $25.9 \%$ structure engineers expressed that the nonstructural members have minor damage after earthquake.

The repair, restore and retrofitting works were required to be done in the damaged apartment buildings after earthquake and the structural engineers were asked "What type of repairs are required to be done in the apartment building after Gorkha Earthquake 2015?" and the result is shown in figure 5.

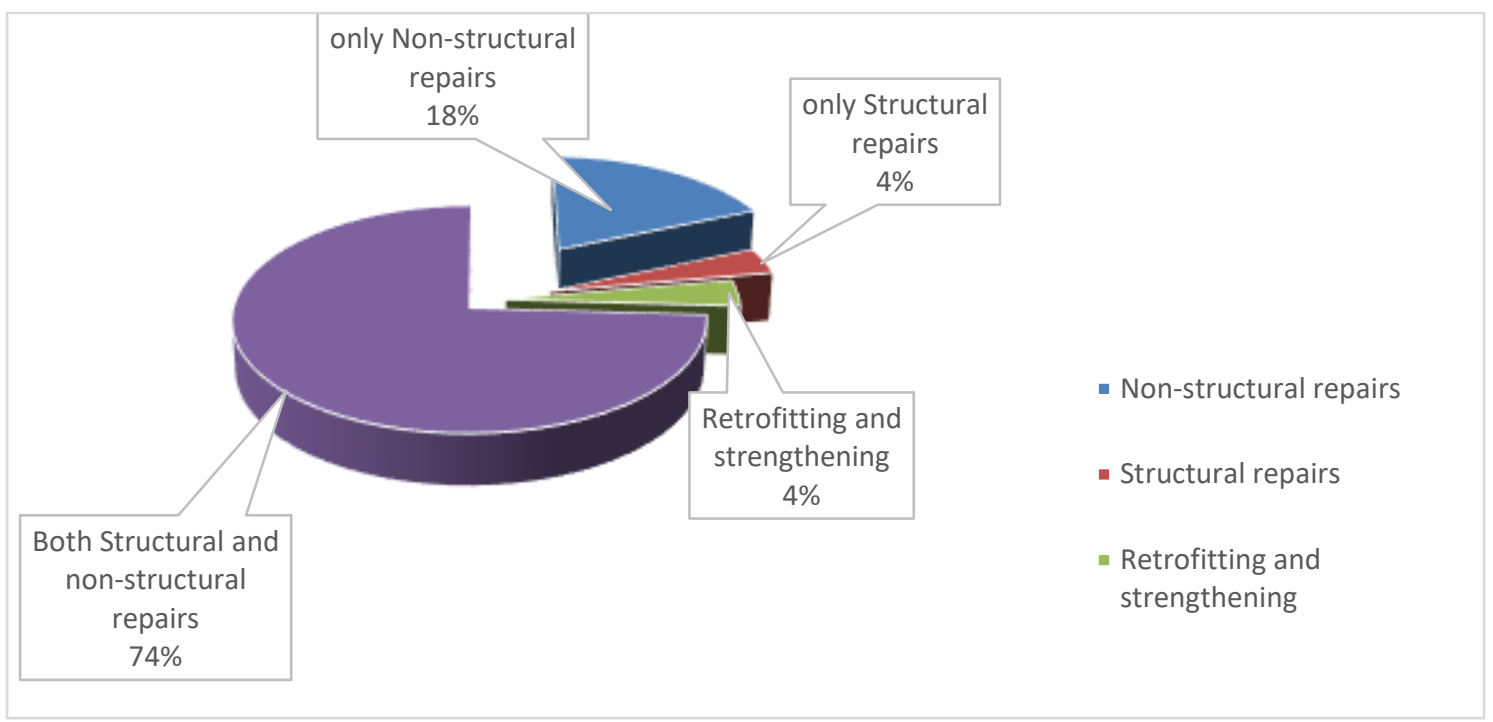

Fig. 5: Type of Repairs required in damaged apartment buildings

Figure 5 shows that according to the views of the structure engineers in $74 \%$ of apartments, both the structural and nonstructural repairs are needed to done, in $18 \%$ apartments, only nonstructural repairs are needed to be done, in $4 \%$ apartments structural repairs are needed to done and in remaining $4 \%$ retrofitting and strengthening is needed to be done after the Grokha Earthquake 2015. This shows that major apartments needed both structural and nonstructural repairs but the retrofitting and strengthening was needed in only few apartments.

Again, both the structure engineers and architects were asked "What shall be done by the concerned authorities during repairing, restoring and retrofitting works of damaged apartment buildings for quality control and compliance as per design?" and different suggestions were given by the respondents however those suggestions were grouped in five category and the result is shown in figure 6 .

Figure 6 shows that $100 \%$ architects and $92.6 \%$ structure engineers' views to done by concerned authority for quality control and compliance as per design during repair restoring and retrofitting were strict supervision and monitoring from dedicated staffs of DUDBC division office Kathmandu, 28.5\% architects and $44.4 \%$ structure engineers' views to be done by concerned authority, where approval of repair restore and retrofitting plan from DoK. Also 7.1\% architects and 51.9\% structure engineers' views were preparation of quality assurance plan and its implementation, $50 \%$ architects' view was third party monitoring and supervision and $29.6 \%$ structure engineers' view was training to technical manpower about repair and retrofit works for quality control and compliance as per design during the 
repair, restoration and retrofitting works.

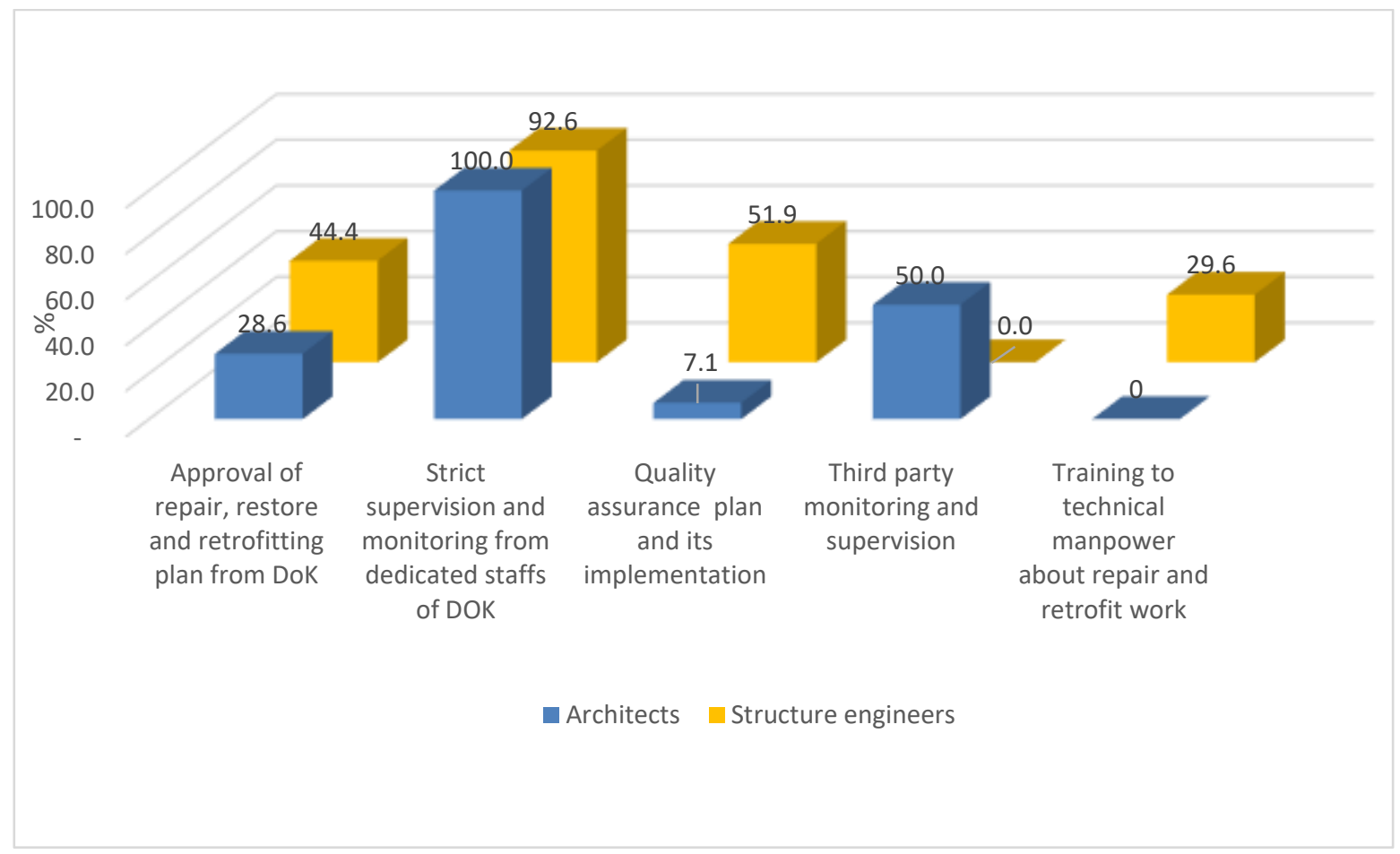

Fig. 6 : Recommendation for quality control during repairs

\section{RECOMMENDATIONS :}

(i) The designer and developer should be made fully responsible and accountable for quality control, quality assurance and compliance of building code and building Bylaws in apartment building construction.

(ii) Rewards and punishment system should be introduced with level of compliance and noncompliance of the provisions of codes and Bylaws.

(iii) Similar study should be conducted for checking compliance of the building code by conducting the Non-Destructive Test (NDT) in all structural members i.e., column, beam, slabs of the apartment buildings.

\section{CONCLUSION :}

\section{Compliance of Building Bylaws and Codes}

$>$ Most of the provisions of the building Bylaws are compiled by all thirteen apartments. However some of the provisions are not complied fully by four apartments.

$>$ Out of the thirteen apartments selected for study, four apartments i.e., Sunrise City homes, Sunrise Towers-I, Silver City Apartment and Guna Colony did not comply minimum greenery open space and Sunrise Apartments and Sunrise Towers-I did not comply setback parameter.

$>$ Most of the provisions of building codes are compiled by all of the thirteen apartments.

However, the RCC bands i.e., sill band, Corner and Tee Stiches and vertical Rebars at corners and Tee junction were not provided by any of the thirteen apartments. Only Lintel band was provided by all the thirteen apartments.

$>$ The quality of most of the apartments are good to satisfactory.

$>$ For effective implementation of Bylaws and codes, the following should be done

- strict monitoring and supervision by DoK,

- Clear role and responsibility should be defined to all concerned authorities for supervision and monitoring

- Designer and Developer should be made accountable and responsible

- third-party verification, supervision and monitoring 
The structural members in most of the apartments during the Gorkha earthquake 2015 were damaged minor to moderate only. But the nonstructural infill walls in most of the apartments were damaged moderate to severely. The main reason for severe to moderate damage on nonstructural infill walls of apartments, was due to the RCC bands and vertical reinforcement not provided in the nonstructural walls.

> So, the RCC bands shall be provided in masonry infill walls and also the nonstructural masonry infill walls should be replaced in apartment buildings by the light weight, prefabricated materials to avoid the damage in masonry infill walls.

From the above, the main conclusion of the study can be made as,

$>$ The apartment building construction is a formal housing process regulated by government of Nepal in overall process of approval, supervision and monitoring.

$>$ The High-rise apartment buildings in Kathmandu valley are safe enough in earthquake, Fire other natural disasters since the compliance of building codes and Bylaws is satisfactory.

$>$ There is no option to go for High-rise Apartment buildings in the cities like Kathmandu where the land is very limited.

\section{REFERENCES}

[1] NPC, 2015. Nepal Earthquake (2015). Post Disaster Needs Assessment, Kathmandu: Government of Nepal, National Planning Commission. https://www.npc.gov.np

[2] Mishra A. K. (2019). Development of Building Bye-Laws in Nepal. J Adv Res Const Urban Arch, 4(3\&4), 17-29. https://doi.org/10.24321/2456.9925.201904.

[3] Mishra, A. K. and Bhattarai, S. K. (2017). Existing Scenario of Building Code Implementation in Newly Formed Nagarjuna Municipality. Asian Journal of Science and Technology, 8(11). 67516762.

[4] Regmi, S. and Mishra A. K., (2020). ASSESSMENT OF KNOWLEDGE AND AWARENESS REGARDING MRT OF NBC; A CASE OF TILOTTAMA MUNICIPALITY, NEPAL. International Journal of Research - GRANTHAALAYAH, 8(07), 50-66. DOI: https://doi.org/10.29121/granthaalayah.v8.i7.2020.545

[5] Mishra A. K., Thing R. (2019) Structural Features for Earthquake-Resistant Load-Bearing Residential Buildings in Nepal. J Adv Res Geo Sci Rem Sens, 6(1), 1-16. DOI: https://doi.org/10.24321/2455.3190.201901.

[6] Mishra A. K. (2019). Cost Implications for the Construction of Earthquake Resistant Load Bearing Residential Building. J Adv Res Geo Sci Rem Sens ; 6(3\&4): 3-15 DOI: https://doi.org/10.24321/2455.3190.201903.

[7] DUDBC, (2015). Report of Rapid Visual Damage Assessment, Kathmandu: Government of Nepal, Ministry of Urban Development, Department of Urban development and Building Construction. https://www.dudbc.gov.np/buildingcode.

[8] DoK, D., (2017). Present Status of Apartment building permit in kathmandu Valley, Kathmandu: Government of Nepal, Ministry of urban Development, Department of Urban Development and Building Construction, Division Office Kathmandu. https://www.dudbc.gov.np.

[9] DUDBC, (2016). NBC Implementation Status in Municipalities, Kathmandu: Government of Nepal, Ministry of Urban Development, Department of Urban Development and Building construction. https://www.dudbc.gov.np/buildingcode. 